\title{
LEUKAEMIC MENINGITIS
}

\author{
BY \\ D. G. COTTOM and G. WETHERLEY-MEIN \\ From the Children's Department and Louis Jenner Laboratory, St. Thomas's Hospital and Medical School, London
}

(RECEIVED FOR PUBLICATION NOVEMBER 14, 1960)

Patients with leukaemia now live longer and have greater opportunity to develop complications both due to therapy and to the disease itself. The treatment of leukaemic infiltration of the meninges has received little attention in this country, possibly because it has been regarded as a terminal event in a fatal disease. This is not necessarily true. Intracranial complications of acute leukaemia are seen in children in haematological remission who are otherwise well. We report here the case of a boy who had two episodes of raised intracranial pressure due to leukaemic infiltration whilst in clinical and haematological remission.

\section{Case Report}

A boy of $4 \frac{3}{4}$ years attended St. Thomas' Hospital because of bone pains, bruising and pallor. $\mathrm{He}$ was found to have a blast cell leukaemia with a haemoglobin of 5.8 g. per $100 \mathrm{ml}$., white cells 20,000 per c.mm. (87\% blast cells) and platelets 35,000 per c.mm. He was transfused with fresh blood and given prednisone $(15 \mathrm{mg}$., t.d.s.) together with 6-mercaptopurine (50 mg., b.d.). His white cell count fell rapidly to 200 per c.mm., but after two weeks his haemoglobin had risen spontaneously and he appeared to be in remission. The dose of prednisone was gradually reduced over the next two months, but maintenance therapy with 6-mercaptopurine $(10 \mathrm{mg}$., b.d.) was continued.

He was seen at weekly intervals, maintained on 6mercaptopurine (10 mg., b.d.) and remained in complete haematological and clinical remission until nine months after the start of the illness when he began to have recurrent headaches which lasted for one hour or more, often associated with nausea. In addition he complained of 'seeing double'. Apart from these transient episodes he was well and refused to stay away from school. $\mathrm{He}$ was found to have bilateral papilloedema, but no other neurological abnormalities were detected. He was afebrile. The blood pressure was $110 / 80 \mathrm{~mm}$. $\mathrm{Hg}$, the liver and spleen were not palpable, there was no bruising and no lymphadenopathy. Haematological studies showed haemoglobin $12.4 \mathrm{~g}$. per $100 \mathrm{ml}$., white cells 5,800 per c.mm. (with no abnormal cells) and platelets 173,000 per c.mm. His bone marrow contained $10 \%$ blast cells, but was otherwise normal.

Lumbar puncture was performed cautiously under general anaesthesia and produced an opalescent fluid under increased pressure (over $300 \mathrm{~cm}$. C.S.F.). The cerebrospinal fluid contained 914 cells per c.mm., mainly leukoblasts, protein $50 \mathrm{mg}$. per $100 \mathrm{ml}$. and glucose $50 \mathrm{mg}$. \%. No organisms were seen. He was treated with three intrathecal injections of $5 \mathrm{mg}$. 'amethopterin' (methotrexate) at intervals of three days and the cells in the cerebrospinal fluid fell to 90 per c.mm., most of which were lymphocytes. Despite this, the cerebrospinal fluid pressure remained over $300 \mathrm{c} . \mathrm{mm}$. Whilst in hospital his headaches ceased and his disc margins became more distinct. A further lumbar puncture one week after the end of treatment showed only 5 cells per c.mm. all of which were lymphocytes. His ocular fundi were almost normal and he was free from symptoms. His blood picture was unaffected by the intrathecal therapy.

For three months after this episode he was clinically and haematologically normal and was maintained on 6-mercaptopurine (10 mg., b.d.). He then had two severe headaches, one of which was associated with vomiting. No abnormal signs were detected and on this occasion his ocular fundi were thought to be normal. From the haematological standpoint his remission continued. Haemoglobin 12.9 g. per $100 \mathrm{ml}$., white cells 6,300 per c.mm. and platelets 365,000 per c.mm. The bone marrow now appeared normal with no excess of blast cells, yet again the cerebrospinal fluid was under increased pressure and contained 372 cells per c.mm. with protein $35 \mathrm{mg}$. per $100 \mathrm{ml}$. He was treated with $5 \mathrm{mg}$. methotrexate intrathecally on three occasions at intervals of three days. There were no further symptoms and when the cerebrospinal fluid was examined four weeks later there were only 10 cells present. He remains well.

\section{Comment}

Intracranial leukaemic infiltration is often found at autopsy. Leidler and Russell (1945) found it in $83 \%$ of a series of 31 cases, yet clinical evidence of involvement of the central nervous system is less commonly noted. It was present in only $20 \%$ of the 334 cases studied by Schwab and Weiss (1935). Since the use of more effective chemotherapy, cases of children receiving such treatment who have developed signs of intracranial involvement are being reported (Poncher, Waisman, Richmond, Horak 
and Limarzi, 1952; Sansone, 1954; Sullivan, 1957; Meneely, 1958; Whiteside, Philips, Dargeon and Burchenal, 1958; Cramblett, 1959; Murphy, 1959). Hamilton and Elion (1954) showed that the concentration of labelled 6-mercaptopurine in cerebral tissue was only one-tenth of that found in blood and that an even greater differential existed between its concentration in blood and cerebrospinal fluid. It appears likely that antimetabolites cross the bloodbrain barrier poorly and that normally effective blood concentrations are unable to inhibit the production of abnormal cells protected within the cerebrospinal axis. It is presumably for this reason that, as in the patient reported here, active intracranial leukaemic proliferation may occur in the absence of clinical, peripheral blood or bone marrow relapse. This finding has two important implications. It suggests that continuous treatment with an antimetabolite inhibits the leukaemic process in the bone marrow and is largely responsible for the maintenance of clinical remission. Secondly, it suggests that autochthonous proliferation of leukaemic cells may take place in situ in the central nervous system and that their presence is not due to infiltration of primitive cells released from the bone marrow.

Intracranial leukaemia may affect either the meninges or the brain itself. In the latter case the child may present with weakness of the extremities and the cerebrospinal fluid usually contains less than 500 cells. Here the response to treatment is less favourable. If, however, the meninges are mainly involved the symptoms are headache, irritability, vomiting and disturbances of vision. The child is found to have papilloedema and there may be radiological evidence of raised intracranial pressure. The cerebrospinal fluid contains an excess of leukoblasts, usually more than 1,000 per c.mm. It is in cases of this predominantly meningeal type that intrathecal methotrexate has been most effective (Murphy, 1959). Methotrexate (0.5 mg. per kg.) is given intrathecally every third to fifth day until the cell count in the cerebrospinal fluid returns to normal. This treatment, which is remarkably non-toxic, is preferable to radiotherapy in that symptoms are more rapidly controlled and there is no likelihood of alopecia.

Since the treatment with intrathecal methotrexate is both simple and effective, it is important to realize that 'leukaemic meningitis' may occur in a child in complete remission. The signs and symptoms of meningeal involvement may, as in the case reported here, be minimal; so headache or any unexplained change of temperament in a child being treated for leukaemia is therefore an indication for a diagnostic lumbar puncture.

We are most grateful to Dr. Ruth Porter of Lederle Laboratories for her prompt help in arranging supplies of intrathecal methotrexate.

\section{REFERENCES}

Cramblett, H. G. (1959). Recognition and treatment of intracranial manifestations of leukemia. A.M.A.J. Dis. Child., 97, 805 .

Hamilton, L. and Elion, G. B. (1954). The fate of 6-mercaptopurine in man. Ann. N.Y. Acad. Sci., 60, 304.

Leidler, F. and Russeli, W. O. (1945). The brain in leukemia. A clinicopathologic study of twenty cases with a review of the literature. Arch. Path. (Chicago), 40, 14

Meneely, A. W. (1958). Leukaemia in children-Ten year survey. Med. Bull. Harrisburg Polyclin. Hosp., 2, 3.

Murphy, M. Lois (1959). Leukemia and lymphoma in children. Pediat. Clin. N. Amer., 6, 611 .

Poncher, H. G., Waisman, H. A., Richmond, J. B., Horak, O. A. and Limarzi, L. R. (1952). Treatment of acute leukemia in children with and without folic acid antagonists. J. Pediat., 41, 377 .

Sansone, G. (1954). Pathomorphosis of acute infantile leukaemia treated with modern therapeutic agents; 'meningoleukaemia' and Frölich's obesity. Ann. paediat. (Basel), 183, 33.

Schwab, R. S. and Weiss, S. (1935). The neurologic aspect of leukemia. Amer. J. med. Sci., 189, 766.

Sullivan, M. P. (1957). Intracranial complications of leukemia in children. Pediatrics, 20, 757.

Whiteside, J. A., Philips, F. S., Dargeon, H. W. and Burchenal, J. H. (1958). Intrathecal amethopterin in neurological manifestations of leukemia. A.M.A. Arch. intern. Med., 101, 279. 